\title{
キサンツレン酸結合型シリカゲルの合成とその環境水中の 微量金属の前濃縮/定量への応用
}

\author{
笠原 一世 ${ }^{\circledR *}$, 寺島 元基 $^{* * *}$, 向山 智子*, 田口 茂 ${ }^{*}$
}

\author{
Synthesis of silica-gel immobilized xanthurenic acid and \\ its application to the preconcentration/determination of \\ trace metals in natural water samples
}

Issei Kasahara, Motoki Terashima, Tomoko MukaIyama and Shigeru Taguchi ${ }^{*}$

\footnotetext{
*Department of Environmental Biology and Chemistry, Faculty of Science, Toyama University, 3190 Gofuku, Toyama-shi, Toyama 930-8555
}

(Received 17 July 1998, Accepted 16 September 1998)

\begin{abstract}
A silica-gel immobilized xanthurenic acid (4,8-dihydroxyquinoline-2-carboxylic acid) was synthesized and its potential as an adsorbent for metal ions was studied. An aminopropylated silica-gel was reacted with 4-aminobenzoic acid in the presence of 1-ethoxycarbonyl-2-ethoxy-1,2-dihydroquinoline (EEDQ) to form aminobenzamide silica-gel. The product was diazotized with sodium nitrite and coupled with xanthurenic acid. The silica-gel immobilized xanthurenic acid had an adsorption capacity of about $50 \mu \mathrm{mol} \mathrm{g}^{-1}$ for copper ion. This is more than twice that for silica-gel immobilized 8-quinolinol by the same method. Copper, lead, and zinc were adsorbed quantitatively from the solution of over $\mathrm{pH}$ 1, 2 and 3, respectively. Cadmium, nickel, cobalt and vanadium were adsorbed over $\mathrm{pH}$ 4. Many metal ions were adsorbed under a more acidic condition than the adsorbent, silica-gel immobilized 8-quinolinol, because xanthurenic acid has a carboxyl group in the structure. The silica-gel immobilized xanthurenic acid was applied to the determination of trace copper, vanadium and nickel ions in river water and seawater samples by ICP-AES or GFAAS after preconcentration. It was possible to determine sub $\mu \mathrm{gdm}^{-3}$ levels of trace metals after a 100 -fold preconcentration using synthesized silica-gel immobilized xanthurenic acid.
\end{abstract}

Keywords : silica-gel immobilized xanthurenic acid; xanthurenic acid (4,8-dihydroxyquinoline-2-carboxylic acid); preconcentration; trace metals; separation.

* 富山大学理学部生物圈環境科学科: $930-8555$ 富山県 富山市五福 3190

** 現在所属 北海道大学大学院地球環境科学研究科: 060-0810 北海道札幌市北区北 10 条西 5 丁目

\section{1 緒言}

環境水中の重金属イオンは, 共存するコロイドや懸濁 物質に吸着して沈降除去されるため, その存在量は $\mathrm{ng}$ $\mathrm{dm}^{-3} \sim \mu \mathrm{g} \mathrm{dm}{ }^{-3}$ と極低濃度である. しかし, 環境水中 の微量金属の挙動を知ることは環境化学, 地球化学, 生 
物学的に重要であり, その定量の必要性がますます高ま りつつある。

一方，誘導結合プラズマ質量分析法 (ICP-MS) ${ }^{1)}$ のよ うな高感度な分析法は, 適切な条件下では $\mathrm{ng} \mathrm{dm}^{-3} レ$ ベルの微量金属の直接定量が可能であるが，マトリック ス成分の分光干渉, マトリックス成分の非分光干渉など といった共存成分の影響を受ける ${ }^{2}$. 又, ICP 発光分析 法（ICP-AES）や黒鉛炉原子吸光法（GFAAS）等を用い て微量金属の高感度定量を行うには, 感度不足を補い, 共存成分からの妨害を除去するために, 目的金属の濃縮 とマトリックス成分からの分離が必要となる2 ${ }^{2)-6)}$.

このような理由から, 環境水中の微量金属の直接定量 は決して容易ではない.すなわち, 分析機器による測定 に先立ち, 目的金属を適切に分離・濃縮するという化学 的な操作が不可欠である.この分離・濃縮の手段として は, 共沈, イオン交換, 溶媒抽出, 固相抽出などを原理 とする様々な方法が開発・報告されている。 なかでも， 近年, 疎水性の吸着剂 ${ }^{3)}$ やメンブランフィルター 用する固相抽出法”が広く用いられるようになってき たそその一つであるカラム濃縮法は, 迅速, 簡便に高い 濃縮倍率が得られること, 吸着剤量を任意に変えること ができ, 更にその吸着剤を比較的容易に化学修飾して改 良することができる点で優れている.

このカラム濃縮法の充てん郕の一つであるキレート試 薬結合型シリカゲルとしては，8-キノリノールを用いる 報告が数多く, 海水のような高マトリックス中の微量成 分分析において, 試料の前処理方法として利用されてい る(i).

著者らは先に, ペプチド合成試薬 1-エトキシカルボ ニル-2-エトキシ-1,2-ジヒドロキノリン（EEDQ）を用い る8-キノリノール結合型シリカゲル \{Fig. 1(c)\} の合 成法7を報告した。この EEDQを用いれば, 穏和な条件 下においてカルボキシル基とアミノ基を結合させること ができる. EEDQとアミノ安息香酸を併用すれば，シ リカゲル表面上へ容易にアミノベンズアミド基を導入で きるのではん用性が高く, 更にジアゾカップリング反応 により簡便にキレート試薬を化学結合できる特長があ る.

一方，フェニルアゾ基を介して 8-キノリノールを結 合させたシリカゲル吸着容量は，一般に $10 \sim 20 \mu \mathrm{mol}$ $\mathrm{g}^{-1}$ 程度と小さく, 多様な環境水に対応するには, より 吸着容量の大きな吸着剤が要求される。そこで, より大 きな吸着容量を有し，かつ高い選択性を持つ吸着郕の開 発を目指している. 本研究では, カルボキシル基を持つ 8-キノリノール誘導体の一つであるキサンッレン酸に着<smiles>CO[Si](CCCCNC(=O)c1ccc(N=Nc2ccc(O)c3nc(C(=O)O)ccc23)cc1)(O[Si])C(C)C</smiles><smiles>CC(C)[Si](C)(O)CCCCNC(=O)Nc1cc(O)c2cccc(O)c2n1</smiles>

(b)

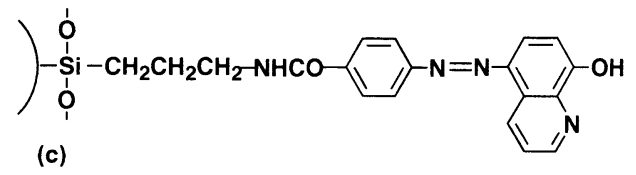

Fig. 1 Structure of the silica-gel immobilized 8quinolinol derivatives

(a) : silica-gel immobilized xanthurenic acid; (b): silica-gel immobilized 4, 8-dihydroxyquinoline; (c): silica-gel immobilized 8-quinolinol

目し，上述の EEDQを用いて，Fig. 1(a)，（b）に示す ような 2 種類の吸着剤を合成した。一つは，(a）フェ ニルアゾ基を介してキサンッレン酸を結合させたもの (キサンッレン酸結合型シリカゲル) であり, もう一っ は（b）キサンッレン酸のカルボキシル基を利用して, 4,8-ジヒドロキシキノリンを結合させたものである. して, 新たに開発した吸着剤のうち, 吸着容量が大きく, 耐久性に優れたキサンツレン酸結合型シリカゲルについ て, 金属イオンの吸着挙動, 濃縮倍率, 回収率等を検討 した後，これを環境水中の微量金属の前濃縮定量に応用 した.

\section{2 実験}

\section{$2 \cdot 1$ 装置及び器具}

ICP-AES は，日立製作所製 Model 306 ICP-AES 使用 した.ニッケルの定量には，日立製作所製 Z- 8000 型偏 光ゼーマン原子吸光分析を用いた。これらの使用条件を まとめて Table 1 に示す.

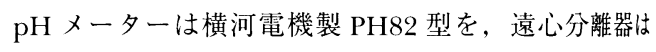
日立製作所製 SCT 5BB 型を用いた。

TLC 板は Merck 製 Keiselgel 60F254を用いた。

\section{$\mathbf{2} \cdot \mathbf{2}$ 試 薬}

アミノプロピル化シリカゲルには, カラムクロマトク ラフ用球状シリカゲル Chromatorex NHDM2035SG（富 
Teble 1 Instrumental conditions for ICP-AES and GFAAS

\begin{tabular}{|c|c|}
\hline \multicolumn{2}{|l|}{ (ICP-AES) } \\
\hline Rf incident power $/ \mathrm{W}$ & 1000 \\
\hline Rf reflected power/W & 0 \\
\hline Ar cooling gas & \\
\hline flow rate $/ \mathrm{dm}^{3} \mathrm{~min}^{-1}$ & 15 \\
\hline $\begin{array}{l}\text { Ar auxiliary gas } \\
\text { flow rate } / \mathrm{dm}^{3} \mathrm{~min}^{-1}\end{array}$ & 0.5 \\
\hline $\begin{array}{l}\text { Ar nibulizer gas } \\
\text { flow rate } / \mathrm{dm}^{3} \mathrm{~min}^{-1}\end{array}$ & 0.5 \\
\hline Entrance slit/mm & 0.03 \\
\hline Exit slit $/ \mathrm{mm}$ & 0.03 \\
\hline Monochrometor & $\begin{array}{l}\text { Cerny-Turner, } 750 \mathrm{~mm} \\
\text { focal length }\end{array}$ \\
\hline Grating & 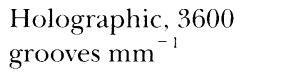 \\
\hline Nebulizer & $\begin{array}{l}\text { Pneumatic concentric } \\
\text { type }\end{array}$ \\
\hline Analytical emission line & $\begin{array}{l}\mathrm{Cu} 324.754 \mathrm{~nm} \\
\mathrm{Ni} 231.604 \mathrm{~nm} \\
\mathrm{~V} 309.311 \mathrm{~nm} \\
\text { Zn } 213.856 \mathrm{~nm}\end{array}$ \\
\hline \multicolumn{2}{|l|}{ (GFAAS) } \\
\hline Wavelength for $\mathrm{Ni}$ & $232.0 \mathrm{~nm}$ \\
\hline Slit & $1.3 \mathrm{~nm}$ \\
\hline Ar carrier gas & $200 \mathrm{~cm}^{3} \mathrm{~min}^{-1}$ \\
\hline Ar interrupted gas & $30 \mathrm{~cm}^{3} \mathrm{~min}^{-1}$ \\
\hline \multicolumn{2}{|l|}{ Temperature program } \\
\hline Drying & $80 \rightarrow 120^{\circ} \mathrm{C}^{\mathrm{a}} \quad(30 \mathrm{~s})$ \\
\hline Ashing & $700^{\circ} \mathrm{C} \quad(30 \mathrm{~s})$ \\
\hline Atomization & $2700^{\circ} \mathrm{C} \quad(10 \mathrm{~s})$ \\
\hline Cleaning & $2800^{\circ} \mathrm{C} \quad(3 \mathrm{~s})$ \\
\hline
\end{tabular}

a) Ramp mode

士シリシア化学製, 表面積 $226 \mathrm{~m}^{2} / \mathrm{g}$, 平均粒子径 60 $\mu \mathrm{m}$ ）を用いた，塩酸は，多摩化学製高純度分析用試薬 TAMAPURE-AA-100 塩酸, 又は市販特級品をサブボイ リング法によって蒸留精製して使用した。硝酸は，多摩 化学製高純度分析用試薬 TAMAPURE-AA-100 硝酸を用 いた。

キサンツレン酸は，東京化成製を使った，金属標準液 は和光純薬製原子吸光分析用標準原液, 又は市販の特級 品から調製したものを用いた。

水は, 蒸留水を Millipore 製 Milli-Q II で精製した.

その他の試薬はすべて市販特級品を用いた.

なお, 緩衝溶液からの金属の污染を防ぎ, 空試験值を 小さくするため, 酢酸緩衝溶液は, あらかじめキサンッ レン酸結合型シリカゲルを詰めたカラムに通すことによ って精製したものを用いた。

\section{$2 \cdot 3$ キサンツレン酸結合型シリカゲルの合成}

$2 \cdot 3 \cdot 1$ EEDQ と 4-アミノ安息香酸を用いるキサンツ

酸結合型シリカゲルの合成＼cjkstart密封できるポリテト ラフルオロエチレン（PTFE）製容器にアミノプロピル 化シリカゲル $20 \mathrm{~g}$ を入れ，10\%(w/v) EEDQ/エタノー ル溶液 $50 \mathrm{~cm}^{3}$ と $10 \%(\mathrm{w} / \mathrm{v}) 4$-アミノ安息香酸/エ夕ノ ール溶液 $50 \mathrm{~cm}^{3}$ を加え, 室温 $\left(25^{\circ} \mathrm{C}\right)$ で 24 時間放置し た，洗浄液中に未反応の試薬が見られなくなるまで，工 タノールで洗浄した。この試検法として TLCを用いた。 更に, 水で洗浄後, $0^{\circ} \mathrm{C}$ 水水中で容器を冷却しながら $5 \%(\mathrm{w} / \mathrm{v})$ 亜硝酸ナトリウム $-1 \%$ 酢酸溶液 $100 \mathrm{~cm}^{3}$ を 加え，30 分間放置するとシリカゲルは淡黄色となった。 これを冷水で洗浄後， $2 \%(\mathrm{w} / \mathrm{v})$ キサンッレン酸のジメ チルスルホキシド（DMSO）溶液 $50 \mathrm{~cm}^{3}$ を加えて良く 振り混ぜると，シリカゲルは暗赤色に変化した。このシ リカゲルを, エ夕ノール，1 M 塩酸，水の順で洗浄し， 洗液が中性になるまで水で繰り返し洗ってから， $50{ }^{\circ} \mathrm{C}$ で 10 時間乾燥した。

$2 \cdot 3 \cdot 2$ EEDQ とキサンツレン酸を用いる 4,8 :ジヒド ロキシキノリン結合型シリカゲルの合成＼cjkstart密封できる PTFE 製容器にアミノプロピル化シリカゲル $20 \mathrm{~g}$ を入 れ，キサンツレン酸 $1.0 \mathrm{~g}$ と EEDQ $1.5 \mathrm{~g}$ を含む DMSO 溶液 $50 \mathrm{~cm}^{3}$ を加えて 48 時間振り混ぜた。 その後, DMSO, エタノール，1 M 塩酸の順で洗浄し, 洗液が中 性になるまで水洗すると, 淡黄色のシリカゲルが得られ た。これを $50^{\circ} \mathrm{C} て ゙ ~ 10$ 時間乾燥した。

\section{$2 \cdot 4$ 吸着容量の測定}

合成したキレート試薬結合型シリカゲルの吸着容量の 測定は，銅 (II) 溶液を用いてバッチ法で行った。その実 験操作は以下のとおりである。

ポリプロピレン製遠心沈殿管に，溶離液 $10 \mathrm{~cm}^{3}$ で洗 浄し水で十分洗った吸着剂 $0.25 \mathrm{~g}$ と，銅（II）溶液（酢 酸緩衝溶液 $\mathrm{pH} 5.0 ， 0.1 \mathrm{M} \mathrm{NaCl}$ ）を入れた。2 0 分間振 り混ぜた後, 約 1 時間放置し, 更に吸着剂と溶液を遠 心分離して，この上澄み液中の銅濃度を ICP-AES で測 定した。又, 吸着剤は脱イオン水 $30 \mathrm{~cm}^{3}$ で洗浄し, 溶 離液 ( $2 \mathrm{M} \mathrm{HCl}$ と $0.1 \mathrm{M} \mathrm{HNO}_{3}$ となるよう調製した混液) $10 \mathrm{~cm}^{3}$ を加えて 15 分間放置した後, その溶離液中の銅 濃度を同様に測定した。

デー夕解析は, 一色らの報告 ${ }^{8)}$ 参考にして行った。

\section{$2 \cdot 5$ 前濃縮/定量操作}

キサンツレン酸結合型シリカゲル $1.0 \mathrm{~g}$ を充てんした リザーバー付きカラム（カラム部分： $100 \mathrm{~mm} \times 10 \mathrm{~mm}$ 


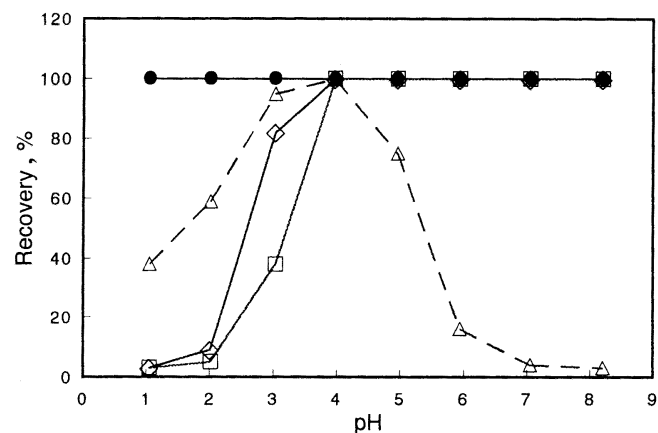

Fig. 2 Effect of pH on the recovery of copper, molybdenum, nickel and cadmium on a silica-gel immobilized xanthurenic acid

10 fold preconcentration of $0.1 \mathrm{mg} \mathrm{dm}^{-3}$ each metal ions. $: \mathrm{Cu}(\mathrm{II}) ; \triangle: \mathrm{Mo}(\mathrm{VI}) ; \square: \mathrm{Ni}(\mathrm{II}) ; \diamond:$ Cd(II)

i.d., 充てん層長さ $25 \mathrm{~mm}$ ，下部に二方コック付き）に， 緩衝溶液を加えて $\mathrm{pH}$ を 4 から 5 に調整した試料水 (100 倍濃縮のときは $\left.1.0 \mathrm{dm}^{3}\right)$ を, 減圧下で吸引しなが ら, 流量約 $30 \mathrm{~cm}^{3} \mathrm{~min}^{-1}$ で通した。少量の水で吸着剂 を洗浄した後, 溶離液的 $10 \mathrm{ml}$ をカラムに注ぎ, 下部の 二方コックを閉じた。 約 15 分間放置後, コックを開い て吸着した金属を $10 \mathrm{ml}$ メスフラスコに溶出し, 更に洗 液を加えて標線を合わせた。この溶離液中の金属の濃度 をICP-AESで測定した。なお, 試料水の体積量を適宜 変えることによって濃縮倍率を調節することができる.

\section{3 結果及び考察}

\section{$3 \cdot 1$ 吸着容量の比較}

EEDQを用いて合成した 8-キノリノール結合型シリ カゲル $\{$ Fig. 1(c)\} の吸着容量は，およそ 15〜20 $\mu \mathrm{mol} \mathrm{g}^{-1}$ であった. 一方，4,8-ジヒドロキシキノリン結 合型シリカゲル $\{$ Fig. 1(b)\} の吸着容量は約 $15 \mu \mathrm{mol}$ $\mathrm{g}^{-1}$ であるのに対し，キサンツレン酸結合型シリカゲル \{Fig. 1(a)\}の吸着容量は 2 倍以上の約 $50 \mu \mathrm{mol} \mathrm{g}^{-1}$ で あった. Fig. 1 に示す構造から推察すると，8-キノリノ 一ル結合型シリカゲルや 4,8-ジヒドロキシキノリン結合 型シリカゲルの場合には，金属イオンが配位できる部分 が 1 か所であるのに対し，キサンッレン酸結合型シリ カゲルでは, 金属イオンへの配位が可能な部位が 2 か 所ある.このことが，吸着容量が増大した理由の一つと して考えられる.

本研究では, 以下, 吸着容量の大きなこのキサンッレ ン酸結合型シリカゲルを用いて検討を行うことにした。

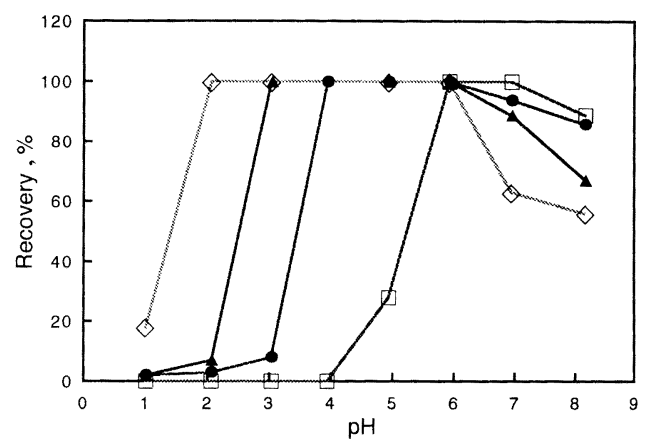

Fig. 3 Effect of pH on the recovery of lead, zinc, cobalt and manganese on a silica-gel immobilized xanthurenic acid

10 fold preconcentration of $0.1 \mathrm{mg} \mathrm{dm}^{-3}$ each metal ions. $\diamond: \mathrm{Pb}(\mathrm{II}) ; \boldsymbol{\Delta}: \mathrm{Zn}(\mathrm{II}) ; \bigcirc: \mathrm{Co}(\mathrm{II}) ; \square:$ $\mathrm{Mn}(\mathrm{II})$

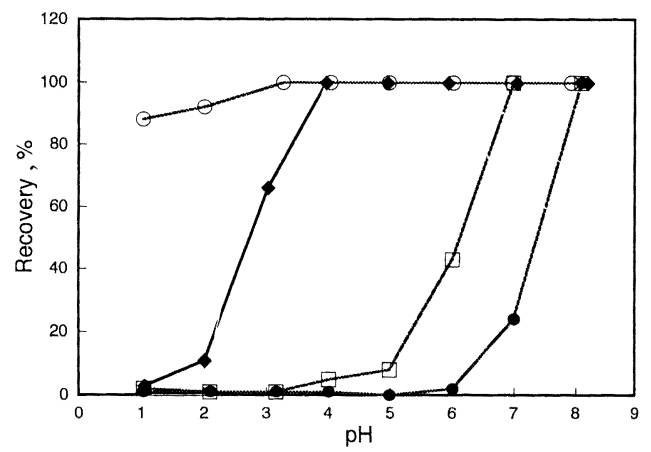

Fig. 4 Effect of $\mathrm{pH}$ on the recovery of vanadium, calcium and magnesium on a silica-gel immobilized xanthurenic acid

10 fold preconcentration of $0.1 \mathrm{mg} \mathrm{dm}^{-3}$ each metal ions. $\bigcirc: \mathrm{V}(\mathrm{V}) ;$ : (IV) $\square: \mathrm{Ca}(\mathrm{II}) ; \bigcirc: \mathrm{Mg}(\mathrm{II})$

\section{$3 \cdot 2 \mathrm{pH}$ と金属イオンの吸着挙動}

キサンツレン酸結合型シリカゲルについて, 溶液の $\mathrm{pH}$ と各種の金属イオンの吸着挙動の関係を, Fig. 2 4 に示した。

銅 (II), 鉛(II), 亜鉛(II) はそれぞれ $\mathrm{pH} \mathrm{1,} \mathrm{2,} 3$ 以 上, カドミウム (II), ニッケル (II), コバルト (II)は, いずれも $\mathrm{pH} 4$ 以上において定量的に吸着された。この 結果は，8-キノリノール結合型シリカゲルの場合に比 べ，全般的に酸性側から吸着されることを示す。これ は, キサンツレン酸がカルボキシル基を有すること, 又 8-キノリノールは二座配位子であるのに対し，キサンッ 
Teble 2 Analytical results (in $\mu \mathrm{g} \mathrm{dm}^{-3}$ ) of copper, vanadium and nickel in natural water samples

\begin{tabular}{|c|c|c|c|c|c|}
\hline \multirow{2}{*}{\multicolumn{2}{|c|}{ Sample name and sampling location }} & \multirow{2}{*}{ Sampling date } & \multicolumn{3}{|c|}{ Analytical results $/ \mu \mathrm{g} \mathrm{dm}^{-3}$} \\
\hline & & & Copper & Vanadium & Nickel \\
\hline \multicolumn{6}{|l|}{ River water } \\
\hline & $\begin{array}{l}\text { Jinzu river } \\
\text { (Toyama) }\end{array}$ & Jan 30, 1998 & $\begin{array}{c}1.61 \pm 0.1 \\
(n=3)\end{array}$ & $\begin{array}{c}0.47 \pm 0.01 \\
\quad(n=3)\end{array}$ & $\begin{array}{c}<1.0 \\
{[0.10 \pm 0.03]} \\
(n=3)\end{array}$ \\
\hline \multirow[t]{2}{*}{$\begin{array}{l}\text { Seawater } \\
\text { (Surface seawater) }\end{array}$} & $\begin{array}{l}\text { Kamogaura } \\
\text { (Ishikawa) }\end{array}$ & Feb 5, 1997 & $\begin{array}{c}0.41 \\
(n=2)\end{array}$ & $\begin{array}{c}2.0 \pm 0.2 \\
(n=3)\end{array}$ & $\begin{array}{c}<1.0 \\
{[0.20 \pm 0.04]} \\
(n=3)\end{array}$ \\
\hline & $\begin{array}{l}\text { Kamogaura } \\
\text { (Ishikawa) }\end{array}$ & Sep 16,1997 & $\begin{array}{c}2.1 \pm 0.2 \\
(n=3)\end{array}$ & $\begin{array}{c}1.1 \pm 0.03 \\
(n=3)\end{array}$ & $\begin{array}{c}<1.0 \\
{[0.35 \pm 0.05]} \\
\quad(n=3)\end{array}$ \\
\hline \multirow[t]{3}{*}{$\begin{array}{l}\text { (Deep seawater: } \\
321 \text { m depth) }\end{array}$} & $\begin{array}{l}\text { Namerikawa } \\
\text { (Toyama) }\end{array}$ & Feb 6, 1998 & $\begin{array}{c}0.23 \pm 0.06 \\
(n=3)\end{array}$ & $\begin{array}{l}1.6 \pm 0.03 \\
(n=3)\end{array}$ & $\begin{array}{c}<1.0 \\
{[0.16 \pm 0.04]} \\
\quad(n=3)\end{array}$ \\
\hline & $\begin{array}{l}\text { Namerikawa* } \\
\text { (Toyama) }\end{array}$ & Feb 6, 1998 & $\begin{array}{c}0.74 \\
(n=1)\end{array}$ & $\begin{array}{c}1.6 \\
(n=1)\end{array}$ & $\begin{array}{c}<1.0 \\
{[0.18]} \\
(n=1)\end{array}$ \\
\hline & $\begin{array}{l}\text { Namerikama** } \\
\text { (Toyama) }\end{array}$ & Feb 6, 1998 & $\begin{array}{c}1.23 \\
(n=1)\end{array}$ & $\begin{array}{c}1.6 \\
(n=1)\end{array}$ & $\begin{array}{c}<1.0 \\
{[0.22]} \\
(n=1)\end{array}$ \\
\hline
\end{tabular}

The data shown represents mean \pm standard deviation. The value in bracket is the analytical result by GFAAS. $n$ : number of determination. ${ }^{*}$ Analyzed one month later after sampling. ${ }^{* *}$ Analyzed six months later after sampling.

レン酸は三座配位子として金属イオンと反応する可能性 があることなどに起因すると推定される，一方，カルボ キシル基と親和性が高いと考えられるカルシウム(II), マグネシウム (II) も，8-キノリノール結合型の場合に比 べてより酸性側から吸着されたが, 多くの重金属もより 低い $\mathrm{pH}$ 領域に扔いて定量的に吸着されることから，ア ルカリ土類金属からの分離に扔いて問題は少ないと考え られる．金属分析用の試料水を酸性にして保存すること を考えると，より低い $\mathrm{pH}$ 条件下で重金属イオンを吸着 できることは，濃縮分離を行う際に污染の可能性の高い アルカリ溶液の使用量が少なくて済むため長所である.

バナジウムは，水中では四価と五価の酸化状態をとり うると言われ, 近年, 天然水中の四価と五価のバナジウ 么の分別定量の結果も報告されている. バナジウム $(\mathrm{V})$ は $\mathrm{pH} 3$ 以上，バナジウム (IV) は $\mathrm{pH} 4$ 以上の条件で定 量的に吸着されるが, 両者を $\mathrm{pH}$ 調整だけで分離するこ とは難しい，このため, 実試料の分析にこの吸着剤を応 用したときは，バナジウム (V) とバナジウム (IV)の合 量が測定される.

\section{$3 \cdot 3$ 流量の影響と濃縮倍率及び耐久性}

前濃縮を行うときにカラムに通す試料水の流量を 25 $\sim 40 \mathrm{~cm}^{3} \mathrm{~min}^{-1}$ と相当に高くしても, 銅, バナジウム, ニッケル，亜鉛は定量的に吸着された。

100 倍濃縮における, 銅, バナジウム, ニッケル, 覀 鉛の回收率 $(\mathrm{pH} \mathrm{5.0,5}$ 回測定) は, それぞれ $106 \pm 4$, $100 \pm 3,102 \pm 3,105 \pm 6 \%$ となり，100 倍濃縮を行う ことによって, $\mu \mathrm{g} \sim$ サブ $\mu \mathrm{g} \mathrm{dm}^{-3}$ レベルの標準溶液中 の金属を ICP-AES で測定することが可能であった.

又, このキサンッレン酸結合型シリカゲルは, 少なく とも20 回の繰り返し使用に耐えた.

$3 \cdot 3 \cdot 1$ 添加回収実験 環境水中には, 目的金属以 外にも様々な共存物質が含まれており，これらがときに 定量を妨害することがある. そこで, 河川水と海水試料 について, 銅 (II), バナジウム $(\mathrm{V})$, ニッヶル (II), 带鉛 （II）を添加し，その回収実験を行った. 採水した試料水 は, 直ちにホウケイ酸ガラスファイバーフィルターで洰 過し, $0.1 \mathrm{M}$ 硝酸酸性にした。この試料水 $1.0 \mathrm{dm}^{3} に$, 上述の金属イオンを $0,1,2,3 \mu \mathrm{g}$ 添加し，100 倍濃縮 後の各金属イオン濃度を測定した。このようにして得ら れた直線の傾きと検量線の傾きを比べたところ，銅(II), 
バナジゥム $(\mathrm{V})$, ニッケル $(\mathrm{II})$ は，その傾きが等しくな った，しかし，亜鉛(II) は，それぞれの直線の傾きが異 なり，共存物質の影響を受けることが示唆されたが原因 は不明である。

$3 \cdot 3 \cdot 2$ 実試料分析への応用 本法を河川水や海水 など自然水中の銅，ニッケル及びバナジウムの定量に応 用した結果を Table 2 に示した、銅，バナジウムはサ ブ $\mu \mathrm{g} \mathrm{dm}^{-3} \sim \mu \mathrm{g} \mathrm{dm}^{-3}$ のレベルをICP-AESにより定量 することができたが，ニッケルは 100 倍濃縮してもま だICP-AES の感度が不足したので, GFAAS で定量した。 石川県輪島市鴨ケ浦は, 1997 年 1 月のロシア船籍夕ン カー「ナホトカ号」から流出した重油が漂着した海岸で ある．重油には，バナジウムやニッケルが含まれている ことから, 鴨ケ浦で採取した海水に, 重油起源のバナジ ウム，ニッケルによる污染が見られるか調べた。しか し, 冬と夏に採水した二つの試料水の分析結果は, バナ ジウム, ニッケル共に平均的な海水中の濃度 ${ }^{10)}$ と大差が なかった、ただ，重油中のバナジウム，ニッケルは主に ポルフィリン錯体として存在している(1112)こと, 又この 錯体は一般に安定で, $\mathrm{pH} 1$ くらいでは分解しないこと から，遊離のバナジウムやニッケルのみを吸着するキサ ンツレン酸結合型シリカゲルでは，このポルフィリン錯 体を捕らえることができないと考えられる．従って，こ の結果のみからは重油起源のバナジウム，ニッケルが全 くないとは言えない。又，1997 年 9 月 16 日に採水した 試料水中の銅の濃度が比較的高い值を示しているが，こ れは河川水の流入の影響, 又は容器などからの污染と考 えられる. 滑川の海水試料は, 滑川漁港沖合い $2.6 \mathrm{~km}$ の地点の水深 $321 \mathrm{~m}$ の深層水をくみ上げたものである. この海水中の銅, バナジウム, ニッケルの濃度は, 標準 的な海水の值 ${ }^{10)} に$ 近いことが分かった。この哚層水試料 をポリエチレン製タンク (容量 $\left.5 \mathrm{dm}^{3}\right)$ に入れ， $0.1 \mathrm{M}$ 硝酸酸性として保存し, 約 1 か月後及び約 6 か月後に 再び測定を行ったところ, 銅の濃度がそれぞれ，約 3 倍及び約 5 倍に増加していた。試料数 $n$ は 1 で少ない
が, Table 2 から分かるようにバナジウムやニッケルの 濃度にほほ変化がないことに比べ，銅の濃度はしだいに 増加する傾向が認められた。この原因として, 溶存して いた㲘濁物質の溶解に伴う銅の溶出, 容器からの污染な どが考えられる。

本研究の一部は文部省科学研究費補助金(課題番号 09640719）によって行われた。ここに記して謝意を表す。

$$
\left(\begin{array}{l}
1998 \text { 年 } 5 \text { 月, 第 } 59 \text { 回分析化 } \\
\text { 学討論会に拈いて一部発表 }
\end{array}\right)
$$

\section{文献}

1) 原口紘栗，寺前紀夫，古田直紀，猿渡英之訳： “微量元素分析の実際”, (1995), (丸善); C. Vandecasteele and C. B. Block: "Modern Method for Trace Element Determination", (1993), (J. Willy \& Sons, West Sussex) \}.

2) 原口紘昰，稲垣和三：ぶんせき (Bunseki), 1998, 494.

3) R. E. Sturgeon, S. S. Berman, S. N. Willie: Talanta, 29, 167 (1982).

4) 田口 茂, 榊原美智恵, 滝川直美, 東谷昌彦, 波多宣子，笠原一世: 水処理技術, 36, 597 (1995).

5) 大関邦夫，棣塚いそし：ぶんせき (Bunseki), 1998, 86

6) R. A. Nickson, S. J. Hill, P. J. Worsfold: Anal. Proc. (London), 32, 387 (1995).

7) 笠原一世，高山典子，山本弘美，桜井一英，田 口茂：分析化学 (Bunseki Kagaku), 46, 211 (1997)

8) 一色健司，河野 綾，橋田千寿：第 54 回分析化 学討論会講演要旨集, p. 521 (1993).

9) K. Hirayama, S. Kageyama, N. Unohara: Analyst (London), 119, 1263 (1994).

10) C. S. Wong, E. Boyle, K. W. Bruland, J. D. Burton, E. D. Goldberg (Ed.): "Trace Metals in Sea Water", (1983), (Plenum Press, New York).

11) 柴田康行: 第 6 回環境化学討論会講演要旨集, p. 216 (1997).

12）高橋 務，大道寺英之：“ファーネス原子吸光分 析”p. 152 (1984), (学会出版センター). 


\section{要旨}

表面をアミノプロピル化したシリカゲルに，ペプチド合成試薬 1-エトキシカルボニル-2 エトキシ-1,2ジヒドロキノリン（EEDQ）を用いて，8-キノリノールの誘導体の一つであるキサンッレン酸を結合さ せた 2 種類の吸着剂を合成した。このうち，特にフェニルアゾ基を介してキサンッレン酸をアミド結合 させた吸着剤は, 従来の 8-キノリノール結合型シリカゲルに比べ, 2 倍以上の吸着容量を示した。この 吸着剂について, 水中の微量金属の分離・濃縮用吸着郕としての性質を調べ，更に，これを環境水中の 微量金属 $(\mathrm{Cu}, \mathrm{V}, \mathrm{Ni}$ など）の前濃縮定量に応用した。100 倍濃縮後, ICP-AES 又は GFAAS で測定す ることによって, 河川水や海水試料中の $\mu \mathrm{g} \mathrm{dm}^{-3}$ からサブ $\mu \mathrm{g} \mathrm{dm}{ }^{-3}$ レベルの銅, バナジウム, ニッケル を定量することができた，更に，他の微量金属の濃縮定量にも応用が可能である. 